\title{
Creativity in Somebody Else's Shoes
}

\author{
Kamila Witerska \\ University of Humanities and Economics in Lodz, Poland \\ E-mail address: kamilawiterska@gmail.com
}

ARTICLE INFO

\section{Keywords:}

Drama

Role

Creative problem solving

Developmental factors

\section{Article history:}

Received 17 September 2014

Received in revised form 27 January 2015

Accepted 07 September 2015

ISSN: 2354-0036

DOI: $10.1515 /$ ctra-2015-0022
A B S T R A C T

The paper describes creativity in role context and how drama features and techniques can stimulate creative thinking The first part of the article concerns the role of drama as a stimulator by encasing the participant in fiction. Aspects of development are also taken into account and the areas of differences in the use of drama at various stages of development, and thus at different stages of education are highlighted. The second part of the paper is devoted to drama techniques - heuristics based on taking on a role. The last part of the article describes how drama stimulates the process of solving problems and delineates its specificity.

\section{INTRODUCTION}

The English have a proverb "to be in somebody else's shoes" which means taking somebody else's perspective, their way of thinking. This proverb provides a great opportunity for drama, which is based on taking on a role and trying to solve a problem in somebody else's shoes. Drama stimulates creative thinking by using different heuristics, but always in somebody else's shoes.

Drama can be defined as an educational method, which consists of the active identification of students with fictional roles and situations. It activates the student's knowledge and skills and creates new qualities by launching the operations of cognitive, emotional, sensory and motor activity. Thus understood, drama is defined in the literature as an educational, proper or creative one (Pankowska, 2000; 2013; Somers, 1994; Witerska, 2011).

Creative thinking is developed in drama through the use of a role, drama techniques and stimulating the process of creative problem solving.

\section{THE ROLE}

Firstly, just entering into the role stimulates creativity. It initiates the process of encasing yourself in fiction. You have to think of yourself in a new world in new circumstances. 
The role in drama is closer to a social role than a theatrical one, because it does not require the presentation of a fictional character and the recitation of a dialogue from a script, but is improvised and constantly modified. The role is created during the development of drama and individual interpretation of the form carried out by the student.

There are different ways of placing students in roles, using different drama techniques and other heuristics:

1. Individual not framed (open) role.

The teacher just says:

- You are a writer. Think what kind of writer you are. What are the titles of your works.

- You are a king. Think of yourself as a king. What kind of ruler are you?

- You are birds.

In this case students imagine the role based on their character, personality, knowledge and attitudes. Everybody is different, a writer with various work written, different monarchs, mild and gentle or severe and cruel, crafty or honest and sincere, old or young, ailing or suffering from a particular disease. It depends on the students and allows them to initiate their imagination. In the next step we give the students the context they are in, usually containing a problem. And the role is framed by student's ideas of the character and the circumstances given by the teacher.

2. Framed role.

The teacher says:

- You are a writer, who has just been run out of his country, as he is being persecuted because of the opinions expressed in his text.

- You are a king, who has just won a huge battle. You now have an army of prisoners of war and a big and beautiful neighbouring country that you have conquered.

- You are an animal at a farm. Think what animal you are and why you are important on the farm.

In this case students also imagine the role based on their character, personality, knowledge and attitudes, but they have to adapt to the circumstances given. It is a kind of border, but it does not limit their creativity. It is used to initiate their emotions, engagement, and actions. Bowell and Heap say "A role in drama is simply that - a role. Whether it be scientist, environmentalist, soldier, nurse, wicked stepmother or Pope! But there is no drama until the role is given a viewpoint. That is until it is properly framed. But, if we are soldiers who are $A W O L$, we now have a point of view which is something like 'we are being hunted and we don't want the wrong people to recognize us or we will be punished'. So there is a tension now, and from here we may proceed to the 'why' of the situation" (Bowell \& Heap, 2000, p.63). 
The role created by the student is most commonly the result of his conception of it and the activities of all participants in the drama. It may, therefore be interpreted quite differently from what the teacher expected.

What is more, drama is also dependent on the stage of human development. When we say to children, "You are birds," the children feel like those birds immediately; they start running around the room, waving their hands and making noises as if they were birds. When the same is said to adults they are likely to ask questions: "What birds? Where are we? In a nest? In the woods? Or on a field? What do we do?" Even if we go through the context of these particular birds, the intention and all the organizational aspects of our exercise with them, not all adults will choose to "flutter" around the room.

The above example demonstrates that for taking a role in drama, certain rules governing human development apply. For children, drama is a natural form of expression, a way of thinking and playing. Adults have their thinking verbalized and need different roles and drama forms.

The research studies I conducted (Witerska, 2010; 2011) showed that the basic and essential differences relating to the properties of drama are dependent on the stages of development of students and deal with the three aspects of human development in the following continua:

1. Action - analysis of activities continuum (the aspect of psychophysical development) The child plays the whole role from the very beginning and the analysis, verbalization of experience appears through this action. The child's thinking at primary school level is based on concrete operations (ages 7 to 11) which is the move from sensorimotor (birth to age 2) and preoperational stages (ages 2 to 7 ) to the stage of formal operations (age 11 to Adulthood) (Piaget \& Inhelder, 1999). Children's thinking at primary school level is still strongly associated with their doing. At the next stage of development, students' thinking takes on processes characterized by formal operations and at the same time, motor skills have to be re-negotiated. Re-structuring of motor skills takes place in phase two (at the secondary school level). This re-structuring is varied by gender and it is personalized (Kielar-Turska, 2000). It reveals the ability to predict movements and increases the ability to create new combinations and compositions of movements. High school teachers and university teachers observe that students at this stage of education, experience withdrawn behaviour when they get into role and improvise. As a consequence, drama work usually begins from the "sculpture" setup, which gives students a feeling of safety. Drama lessons with youths and adults start with techniques that use a word or stable expression (e.g. sculpture) in order to encourage the students to become more active. 
2. Concrete - abstraction continuum ( the aspect of cognitive development)

This difference concerns levels of abstract thinking. With primary school pupils, thinking and actions are based on something that relates to a particular fact which is wellknown to them from their experiences. "The child at this stage can form concepts, see relationships, and solve problems, but only as long as they involve objects and situations that are familiar" (Slavin, 2003, p.36). At other stages of education, students work with abstract concepts (e.g. the role of "Collective Conscience", the role of "Sleep").

These findings match the stages of cognitive development posited by Piaget. However, many scholars (e.g. Kohlberg \& Mayer, 2000; Matczak, 2000; Vasta, Haith \& Miller, 1995; Vygotsky, 1989) point to the possibility that abstract thinking can be stimulated and can develop earlier than Piaget believed. Vasta and his colleagues (Vasta, Haith \& Miller, 1995) consider that Piaget's experiments lead to an underestimation of children's competence. They cite several studies that have shown that more intensive training procedures and the simplification of different procedures enabled a triggering of certain elements at the level of formal operations in children under the age of 9 or 10 years. Matczak (2000) also emphasises that, in shaping the preferences of abstract or concrete thinking, the type of educational training undergone plays an important role. Concreteness in cognitive functioning is a product of the suppression of exploration and independence of the child. Kohlberg and Mayer (2000) stress that the educational environment should actively stimulate development through the presentation of problems and conflicts to be solved. Facilitating the transition of a child to the next level of development must take into account the child's discovery of higher-level thinking. So the following are needed:

- diagnosis of the stage;

- fitting the stimulation to the diagnosed stage, that is, giving tasks placed at a stage higher than the current stage;

- creating some cognitive conflicts;

- stimulating activity.

Stimulating a child's abstract thinking is addressed in the concept of learning at the zone of proximal development (Vygotsky, 1989). Tasks within the zone of proximal development are ones that a child cannot yet do alone, but could do with the assistance of somebody more competent. A key idea derived from Vygotsky's notion of social learning is that of scaffolding, that is, the assistance provided by more competent peers or adults. This involves giving the child a great deal of support at the beginning of learning and then reducing support and having the child take on increasing responsibility (Slavin, 2003). 
Therefore, drama in the primary school can be a kind of training in abstract thinking, if the child has the opportunity of making the transition to the level of generalization and the search for universal meanings of their individual experience. In addition, drama exercises should be designed in such a way that will encourage exploration and autonomy of the child.

3. Me - others Continuum (the aspect of psychosocial development)

The Me-Others aspect refers to the difference between the development of students themselves and the development of their attitudes to interpersonal communication. In the light of my research and continuing the metaphor of the dance created by Lang (2004), primary school students and junior high students "dance the group dance", high school students "dance individually", and higher education students "dance in pairs".

Primary school and junior high school students are seeking their place in a group. They are prepared for interaction with other people in order to accept their individualities. Secondary school students are in search of their identity and are building their own "Me". Psychosocial crisis, that is, the conflict between identity and role, specified by Erikson (1997), is considered to be a key for development as a whole. A successful resolution of the crisis is to achieve a stable identity and consciousness. In this period, the adolescent is trying out different roles, shaping constant attitudes and values, and making life choices. Characteristic of high school students participating in drama is a focus on self. Drama gives the student the possibility of taking on various roles and trying them out in safe conditions. In early adulthood there is a stabilization of identity. Attention towards establishing deeper interpersonal relationships appears (Birch \& Malim, 1998). The formation of a stable ego enables the young adult to be more open to the needs of others. In drama lessons, the participants are interested in understanding the behaviour and motives of other people.

\section{DRAMA TECHNIQUES}

Stimulators of creativity in drama are also drama techniques - particularly symbolic and reflective techniques whose aim is unreal drama and going to a deeper level of thinking. Drama techniques are heuristics using the mechanism of taking the role.

Trying to make a synthesis of many, inseparable classifications of drama techniques (Heathcote, 1995; Lewandowska-Kidon, 2001; Neelands and Goode, 2000; Pankowska, 1997). I have singled out four specific categories:

1. Techniques of context allow preparation of the situation, as well as supplementing information on context during the development of the drama.

Examples of techniques:

- guided tour - the form of a story, in which students receive a detailed picture of the environment in which there is drama; 
- attributes - working with objects "belonging" to the main character.

- circle of life - in the middle of a large sheet of paper, a circle is drawn in which the name and age of the character is inscribed. The remainder of the card is divided into four parts, which represent areas of life form and the person with whom the character interacts in a given area. Participants provide ideas for characters that are entered in various parts of the paper.

2. Narrative techniques emphasize the presentation and development of the plot. They focus on important events, which are central elements for the development of the narrative.

Examples of techniques:

- critical events - separation in the form of critical life or turning points;

- overheard conversation - eavesdropping on conversations that normally would not be heard by certain people;

- hot seating - participants ask questions of the person remaining in the role, who is sitting on a chair set in the middle of the room, or standing in the middle of the room.

3. Symbolic techniques emphasize the symbolic potential of drama. They help look over the line plot and seek new meanings.

Examples of techniques:

- metamorphosis - participants create visual elements of the environment by entering the roles of objects;

- analogy - the problem is exposed by working on a similar situation, which is a reflection of the real one;

- gesture - participants of the classes are designed to incorporate the realistic scene of a gesture or sign reflecting the true social relations between the characters. Additionally gesture may include existing contradictions.

4. Reflective techniques allow the extraction of the character's thinking, or adding a psychological comment to their behaviour.

Examples of techniques:

- thought tracking - involves guessing the thoughts of people who are in the roles of the people watching,

- tunnel of thoughts - the person in the role passes between two rows of participants who comment on the situation or give advice.

- voices in the head - participants represent and speak aloud thoughts that have accumulated in the head of one of the characters at a certain moment of her life, or within conflicting roles as a component of collective conscience and conduct an internal dialogue.

In fact every drama technique stimulates creativity, as each of them triggers the imagination and creates a fictional world. If, however, the context and narrative techniques are 
building a fictional world, the symbolic and reflective techniques make drama unrealistic, letting go of the plot line in the direction of its analysis, the search for meaning and solutions to problems.

On the basis of their research, Mitchell and Cooney (2004) formulated several allegations in relation to the practice of drama, which can be described as 5 mistakes made by drama practitioners:

1. promoting the performance instead of the process of creating;

2. working in a well-known, literal context; reducing the need for research and exploration;

3. suppressing efforts to understand by an excessive desire for students to present the results of work;

4. refraining from "creative risk"; likely solutions instead of many possible solutions (probabilities rather than possibilities);

5. not using the richness inherent in practice, not using techniques that may bring out the potential inherent in practice.

According to Mitchell and Cooney (2004) drama teachers should discover what the student knows, understands, what they think and feel, what they want to know and how to help them find this knowledge.

\section{CREATIVE PROBLEM SOLVING IN DRAMA}

Building structures of knowledge and skills is done in drama from the perspective of people involved in a given situation. The students solve problems that are their own dilemmas in the created world, which produces greater commitment, emotionally escalating motivation to act and the search for solutions to problems.

The process of creating meanings in drama is about seeking, formulating and solving problems. This refers to the model of creative problem solving CPS (Creative Problem Solving) built on the basis of the problem-solving model of Dewey (1988) and developed by the theorists of creativity (Isaksen, Dorval \& Treffinger, 1994).

In drama the process of creative problem solving goes in stages, which can also be called creative drama stages:

1. The initial phase

a) Relaxing and focusing exercises (warm-up)

Drama classes begin with exercises to soothe and focus. The purpose of this type of exercise is on the one hand overcoming mental and physical tension of the participants, and on the other hand, the concentration of attention on the task. 
b) The source material and the answer to the source material

When the participants are ready to schedule activities, the teacher presents the material, which is the starting point for drama. The source material may include: names of concepts, texts, objects, photographs, images, sounds, etc. For the presentation of the source material the teacher can use the techniques of context, such as attributes, sound environment, circle of life, etc.

The task for the student is to answer the presented material, determined by a technique or a combination of drama and other methods. The students are part of the relevant information in the schematic drawing of the circle of life or character (the role of the wall), creating the character based on her personal belongings (attributes), and so on.

The responses of students to the source material show their knowledge on specific subjects, attitudes, stereotypes and prejudices, and energizes the motivation to take on a specific topic.

c) Formulation of the problem

Students' answers to the source material reveal different points of view, elements of conflict, conflicting information or attitudes that lead to the determination of the problem situation. The teacher's task at this stage is to lead exercises and discussions, enabling students to bring out the elements of contradiction, conflict, and identification of the problem. For this purpose, they may use the simulation techniques of creative thinking, especially for developing interrogative thinking and cognitive curiosity (see Necka, 2005; Szmidt, 2008; 2013).

The problem in drama is open, so the next stage of the course is the production of many solutions: through actions in the context of the situation and characters, and a strategy of deepening, which allows students to go beyond the literal meaning.

2. Main phase

a) Actions in the context

At this stage students operate in a specific context, namely in imaginary roles in a fictional situation. Narrative techniques are used, which emphasize the presentation and development of the plot, for example: improvised situations, critical events, overheard conversations, hot seating. They focus on important events, accidents, or meetings that are central elements for the development of the action.

b) Generation of meanings and troubleshooting

This essential part of the course is particularly important for using deepening strategies such as the use of symbols or transfer of the problem to another situation, realized through techniques which stimulate the creation of new meanings and troubleshoot- 
ing: symbolic techniques such as metamorphosis, mime, gesture shortcut, and analogy and reflective techniques: thought tracking, or the voices in the head.

3. The last phase - evaluation of the process and the effects of drama

The essence of the last part of the drama is to assess the effects of the work: developed meanings, solutions to problems, and the process of their creation. In this phase the following activities may be used: assessment of characters and situations, generalization - transfer of specific actions in the role to the level of rules, the assessment of solutions to the problem and planning a strategy, assessment of student's own behaviour in a fictional role, the analysis of the process of identifying with the role and building the role, the analysis of the factors stimulating and blocking action. The final part of the drama can be done using drama techniques such as sculpture or tunnel of thoughts, however, it should end with activities outside the role.

\section{REFERENCES}

Birch, A. \& Malim T. (1998). Psychologia rozwojowa w zarysie. Od niemowlectwa do doroslosci [Developmental Psychology in the outline. From infancy to adulthood]. Warsaw: PWN.

Bowell, P. \& Heap, B. (2000). Sign as the concrete manifestation of frame tension in process drama. In Ch. Lawrence Drama Research. The Research Journal of National Drama, 1, April, London: National Drama Publications.

Dewey, J. (1988). Jak myslimy [How we think?]. Warsaw: PWN.

Erikson, E.H. (1997). Dziecinstwo i spoleczenstwo [Childhood and Society]. Poznan: Rebis Publishing House.

Heathcote, D. \& Bolton, G. (1995). Drama for learning: Dorothy Heathcote's mantle of the expert approach to education. Portsmouth: Heinemann.

Isaksen, S.G., Dorval, K.B., Treffinger, D.J. (1994). Creative approaches to problem solving. Dubuque: Kendall/Hunt.

Kielar-Turska, M. (2000). Rozwoj czlowieka w pelnym cyklu zycia [Development of a human in a full life cycle]. Gdansk: GWP.

Kohlberg, L. \& Mayer, R. (2000). Rozwoj jako cel wychowania [Development as a goal of education]. In Z. Kwiecinski (Ed.), Alternatywy myslenia o/dla edukacji [Alternatives thinking about / for education]. Warsaw: IBE.

Lang, L.L. (2004). The dance of power in playbuilding practice. Drama Research 3, June, London: National Drama.

Lewandowska-Kidon, T. (2001). Drama w ksztalceniu pedagogicznym [Drama in teacher training]. Lublin: UMCS. 
Matczak, A. (2000). Style poznawcze [Cognitive Styles]. In J. Strelau (Ed.), Psychologia. Podrecznik akademicki [Psychology. Academic Handbook]. Gdansk: GWP.

Mitchell, L. \& Cooney, P. (2004). Stepping stones into the unknown. Praxis in secondary drama. Drama Research 3, June, London: National Drama.

Neelands, J. \& Goode, T. (2000). Structuring drama work. Cambridge: Cambridge University Press.

Necka, E. (2005). Trening kreatywnosci [Creativity training]. Gdansk: GWP.

Pankowska, K. (1997). Edukacja przez drame [Education through drama]. Warsaw: WSiP.

Pankowska, K. (2000). Pedagogika dramy. Teoria i praktyka [Pedagogy of drama. Theory and practice]. Warsaw: Wydawnictwo Akademickie „Zak”.

Pankowska, K. (2013). Drama. Konteksty teoretyczne [Drama. Theoretical contexts]. Warsaw: WUW.

Piaget, J. \& Inhelder, B. (1999). Psychologia dziecka [Child Psychology]. Wroclaw: Siedmiorog.

Slavin, R. E. (2003). Educational Psychology. Boston: Pearson Education.

Somers, J. (1994). Drama in the Curriculum, London-New York: Cassell.

Szmidt, K.J. (2008). Trening kreatywnosci. Podrecznik dla pedagogow, psychologow $i$ trenerow grupowych [Creativity training. Handbook for teachers, psychologists and group trainers]. Gliwice: HELION.

Szmidt, K. J. (2013). Pedagogika tworczosci [Pedagogy of creativity]. Gdansk: GWP.

Vasta, R., Haith, M.M. \& Miller, S.A. (1995). Psychologia dziecka [Child Psychology]. Warsaw: WSiP.

Vygotsky, L.S. (1989), Myslenie i mowa [Thinking and speech]. Warsaw: PWN.

Way, B. (1998). Development through drama. New York: Humanity Books.

Witerska, K. (2010). Drama na roznych poziomach ksztalcenia [Drama at different educational levels]. Lodz: AHE.

Witerska, K. (2011). Drama. Techniki, strategie, scenariusze [Drama. Techniques, strategies, scenarios]. Warsaw: Difin.

Witerska, K. (2011). How to make them fly? Development frameworks for drama. Drama Research, 2 (1), April, London: National Drama Publications.

Corresponding author at: Kamila Witerska, University of Humanities and Economics in Lodz, 64 Rewolucji 1905r St., 90-222 Lodz, Poland

Email: kamilawiterska@gmail.com

CCopyright by Faculty of Pedagogy and Psychology, University of Bialystok,

20 Swierkowa St., 15-328 Bialystok, Poland tel. +48857457283 